\title{
Article
}

\section{Limits to terror speech in the UK and USA: balancing freedom of expression with national security}

Turner, Ian David

Available at http://clok.uclan.ac.uk/31331/

Turner, Ian David ORCID: 0000-0002-8012-1480 (2020) Limits to terror speech in the UK and USA: balancing freedom of expression with national security. Amicus Curiae, 1 (2). pp. 201-232.

It is advisable to refer to the publisher's version if you intend to cite from the work.

For more information about UCLan's research in this area go to http://www.uclan.ac.uk/researchgroups/ and search for < name of research Group >.

For information about Research generally at UCLan please go to http://www.uclan.ac.uk/research/

All outputs in CLoK are protected by Intellectual Property Rights law, including Copyright law. Copyright, IPR and Moral Rights for the works on this site are retained by the individual authors and/or other copyright owners. Terms and conditions for use of this material are defined in the policies page.

\section{CLoK}

Central Lancashire online Knowledge www.clok.uclan.ac.uk

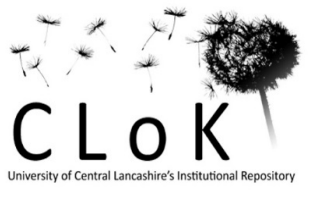




\title{
Limits to TerRor SPEech IN THE UK AND USA: BALANCING FREEdOM OF EXPRESSION With National Security
}

IAN TURNER

Lancashire Law School

\begin{abstract}
Article 10(1) of the European Convention on Human Rights, freedom of expression, is incorporated into UK law. With the growing Islamist terror threat after 9/11, particularly threatening European security, the Council of Europe introduced the Convention on the Prevention of Terrorism (CPT) 2005. One of the Articles within the Convention, Article 5, obliges states to outlaw "public provocation to commit a terrorist offence'. Drawing on its obligations in the CPT, the UK enacted section 1 of the Terrorism Act 2006: 'encouragement of terrorism'. But, in implementing its duties, the UK went further. There are very real concerns, therefore, about the effects of this legislation on freedom of expression. The test for interpreting breaches of Article 10 is 'proportionality'. Comparatively, in America there is a much stronger test than proportionality, 'strict scrutiny', in assessing limits to terror speech. However, in the age of Islamism, together with the speed, ease and little cost incurred in sharing terror speech online, should there not be a reappraisal of American law? The author is based in the UK. But the UK's approach to limiting terror speech is arguably too intrusive of freedom of expression. This paper, therefore, proposes a compromise approach between the two jurisdictions.
\end{abstract}

Keywords: European human rights law, freedom of expression, American constitutional law, First Amendment, encouragement of terrorism, national, regional and international security

\section{[A] INTRODUCTION}

s per the Human Rights Act (HRA) 1998, the European Convention
rights is Article 10(1), freedom of expression. This protects speech that 
either offends, shocks or disturbs, as per the case of Handyside $v$ United Kingdom ${ }^{1}$ at the European Court of Human Rights (ECtHR). Following its obligations in Article 5 of the Council of Europe (CoE) Convention on the Prevention of Terrorism (CPT) 2005, public provocation to commit a terrorist offence, the UK enacted the Terrorism Act 2006, to disrupt Islamists, for example, from exploiting the internet for terrorist purposes. Section 1 of the Terrorism Act 2006 outlaws the encouragement of terrorism. Firstly, there is no need to show a danger that such an offence may be committed, only that it is likely to be understood by some members of the public as an encouragement of terrorism; secondly, in addition to including the intentional encouragement of terrorism, the offence can be committed recklessly. As the offence seemingly exceeds the UK's obligations in the CPT, there are very real concerns, therefore, about the effects of this legislation on freedom of expression. If a person distributes, sells, gives, shares etc. the encouragement of terrorism, they are committing an offence contrary to section 2 of the Terrorism Act 2006, the 'dissemination of terrorist publications'. For example, following the beheading of US journalist James Foley, in 2014, videos of which were posted on YouTube, the British police reminded people not to share the pictures in case of incurring criminal prosecution under section 2 (Halliday 2014).

The test for interpreting breaches of Article 10(1) of the ECHR is 'proportionality', as per Handyside, ${ }^{2}$ that is whether the limitation on expression is merely in proportion to the objective of the state, such as protection of national security, prevention of disorder and crime etc. Where the infringement of Article 10(1) is attributed to terror speech, the courts interpret the proportionality test much more in favour of the state at the expense of the individual, as per Leroy $v$ France. ${ }^{3}$ So, there is almost a double deference shown by the courts to the interests of the state: the test employed, as well as the context in which it is applied.

Comparatively, in the USA, for example, there is a much stronger test than proportionality in assessing content-based interferences with the First Amendment of the Constitution, free speech: 'strict scrutiny'. This follows the ruling of the Supreme Court of the United States (SCOTUS) in

\footnotetext{
1 App no 5493/72, para 49. Note: a draft of this author's paper was presented at the Annual Workshop of the International Association of Constitutional Law Research Group on Constitutional Responses to Terrorism at Bocconi University in Milan, Italy, on 14 June 2019. The author is grateful to a couple of audience participants, Fionnuala Ní Aoláin and Kim Lane Scheppele, for giving him feedback on his presentation.

2 Ibid.

3 App no 36109/03.
} 
Brandenburg $v$ Ohio. ${ }^{4}$ But in the age of Islamist terrorism post 9/11, and the speed, ease and little cost incurred in sharing terror speech online, is the Brandenburg test of 'strict scrutiny' too much in favour of the individual at the expense of the state? America is clearly not subject to European human rights law, but its approach to curtailing rights within the ECHR, especially those that directly conflict with the rights and freedoms of others such as freedom of expression, deserve serious consideration. The author is based in the UK. But the UK's approach to limiting terror speech-indeed Article 10 of the ECHR itself-is arguably too intrusive of speech. This paper, therefore, proposes a compromise approach between the two jurisdictions.

\section{[B] SECURITY THREATS, AND TERROR SPEECH IN PARTICULAR}

Europol, the EU's law enforcement agency, reported that a record number of terrorist attacks - 211 - had been planned, foiled or carried out in EU countries in 2015, the highest since records began in 2006. All of them occurred in just six member states: Denmark, France, Greece, Italy, Spain and the UK (BBC News 2016a). Indeed, the Global Terrorism Index 2018 noted that the number of terrorist incidents in Europe increased to 282 in 2017, which itself was an increase from 2016, when it was 253 (Institute for Economics and Peace 2018). ${ }^{5}$ In the author's own country, the UK, in 2017, 23 people died and 250 people were injured in Manchester when a suicide bomber detonated a suicide vest at an Ariana Grande concert. Also in 2017, there were two terror incidents in London, primarily on London and Westminster Bridges, killing a further 12 people. In addition, a bomb was left on a tube train at Parsons Green, west London, in September of that year, but failed to fully explode. A further nine terrorist attacks, in 2017, were prevented (Johnston 2017). In December 2018, it was reported that the UK authorities were investigating about 700 'live' counter-terrorism cases (Dodd and Halliday 2016). The head of MI6, Britain's secret intelligence service, has recently said that the scale of the terrorism threat facing the UK is 'unprecedented' ( $B B C$ News 2016b). The UK's terror threat level is currently at 'substantial', meaning an attack is likely. Twice in 2017 it was raised to its maximum level, 'critical', meaning an attack was imminent, after the Manchester and Parsons Green attacks.

\footnotetext{
4395 US 444 (1969).

5 But in 2018, in Europe, the number of deaths from terrorism fell to 62-see, for example, Institute for Economics and Peace (2019: 2).
} 
The 'substantial' terror threat to the UK, for example, does not simply come from those who commit, or even prepare, attacks: there are those who ether encourage or instigate them via the worldwide web (Rudner 2017). The internet is the perfect platform for terrorists: it is inexpensive, fast, instantaneous, anonymous and, unlike the traditional print media, permits those intent on hate to control the narrative. It allows for the limitless collection and sharing of terrorist propaganda, across multiple devices, such as home computers and mobile devices. Terrorists can indoctrinate, radicalize, recruit and train new members within closed communities and/or chat rooms, through the media of sermons, instructional videos, blogs, social media-such as Twitter, Facebook, Instagram, WhatsApp and Snapchat-and interactive websites. It also affords terrorists the valuable opportunity to raise funds. ${ }^{6}$ The transnational nature of the web permits terror speech, which has been shut down in one country, to simply find a host in another (Renieris 2009: 676).

In the UK, for instance, the leader of the extremist group alMuhajiroun, Anjem Choudary, was convicted of supporting Islamic State in Iraq and the Levant (ISIL) in July 2016. He was convicted after jurors heard he had sworn an oath of allegiance to ISIL. He had also urged followers to support ISIL in a series of broadcasts on YouTube: supporters were told to obey Abu Bakr al-Baghdadi, the ISIL leader, and travel to Syria (Grierson et al 2016). Choudary is reported to have influenced at least 100 British jihadis (Dodd and Grierson 2016). But, because of free speech concerns, social media platforms were reluctant to remove Choudary's online posts, even after he was arrested for inviting support for ISIL. British authorities allegedly made repeated efforts to have his Twitter posts and YouTube videos removed, but they had no power to force corporations to remove material from the internet even if it had breached UK anti-terror laws. In August 2016, even after Choudary had been convicted, he had more than 32,000 followers on Twitter and his account could still be viewed online, despite requests for its removal in August 2015 and the following March (Press Association 2016). Maybe because of repeated criticism from foreign governments about the hosting of terror material on their platforms, in June 2017 Facebook, Microsoft, Twitter and YouTube formed the Global Internet Forum to Counter Terrorism (GIFCT). The objective of GIFCT is 'to substantially disrupt terrorists' ability to promote terrorism, disseminate violent extremist propaganda, and exploit or glorify real-world acts of violence using our

6 For a general discussion of the internet as an 'indispensable medium' for terrorists, see, for example, Tsesis (2017: 655-62). 
platforms'. ${ }^{7}$ GIFCT claims, for example, that between July 2017 and December 2017, a total of 274,460 Twitter accounts were permanently suspended for violations related to the promotion of terrorism. Of those suspensions, 93\% consisted of accounts flagged by internal, proprietary spam-fighting tools, while $74 \%$ of those accounts were suspended before their first tweet. ${ }^{8}$ In addition, 99\% of ISIL and Al Qaeda-related terror content that is removed from Facebook is content that is detected before anyone in its community has flagged it, and, in some cases, before it goes live on the site. Once Facebook is aware of a piece of terror content, it claims to removes $83 \%$ of subsequently uploaded copies within one hour of upload. ${ }^{9}$ However, later, in January 2018, the then British Prime Minister, Theresa May, called on social media platforms to do more to combat terrorism (Stewart and Elgot 2018). And more recently, in March 2019, there were multiple shootings by a far-right terrorist, Brenton Tarrant, at two Mosques in Christchurch, New Zealand, killing 50 people, which Tarrant livestreamed for 17 minutes on Facebook. ${ }^{10}$ Although the original footage was removed by Facebook after an hour, it was repeatedly re-uploaded by other users (Waterson 2019).

\section{[C] THE ENDURING INFLUENCE OF INCITING TERROR VIOLENCE ONLINE: THE CASE OF ANWAR AL-AWLAKI}

In 2010 the British domestic security services, MI5, feared that a new generation of British extremists were being radicalized online by Anwar al-Awlaki, who at the time was regarded as one of the world's most-wanted terrorists. Al-Awlaki, who was born in America, but was of Yemeni descent, was in hiding in Yemen. He had become the foremost influence on young radical Muslims across the world through his English-language sermons delivered over the internet. In the UK, for example, he developed a following among terrorists and terrorist groomers, including, in 2005, the $7 / 7$ and $21 / 7$ bombers in London. CDs of his sermons were found in the Iqra bookshop in Leeds-where the bombers had held meetingswhen it was raided. In 2009 a UK government analysis of YouTube found that al-Awlaki had 1910 videos on the site, one of which had been viewed 164,420 times (Gardham and Coughlin 2010). Moreover, in 2010, Roshonara Choudhry, a 21-year-old student, was jailed for life for trying

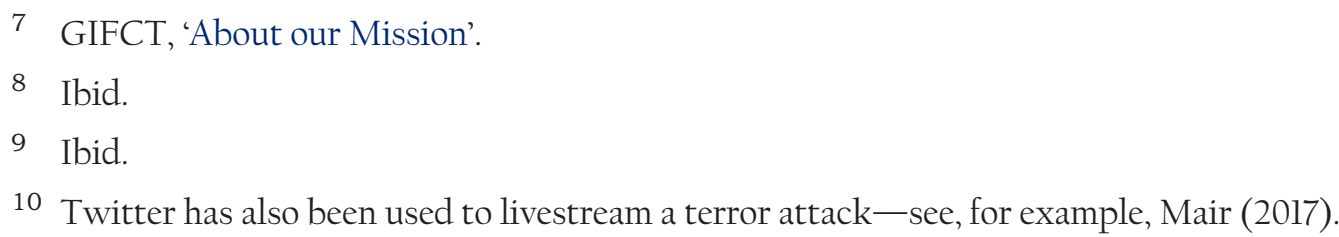

Winter 2020 
to murder the Labour MP Stephen Timms because he had voted for the war in Iraq. Choudhry stabbed the MP twice in the stomach at a constituency surgery in east London. The student had become radicalized after watching online sermons by al-Awlaki (BBC News 2010).

Anwar al-Awlaki had a significant influence beyond the UK because of the reach of the internet. Major Nidal Hasan, for example, who had killed 13 people at the Fort Hood military base in Texas in 2009, had asked for al-Awlaki's advice in emails about a suicide attack (Kenbar 2013). After the attack, al-Awlaki bragged that Hasan was his student and defended the murder spree as 'a heroic act' and 'a wonderful operation' (Tsesis 2018: 660). Also, in 2009, following the influence of al-Awlaki, Umar Farouk Abdulmutallab, a Nigerian, was recruited by Al Qaeda to blow up an American airliner approaching Detroit, but the bomb did not explode. Abdulmutallab told FBI agents that, with guidance from al-Awlaki, he had 'worked through all [the] issues' (Shane 2017). Anwar al-Awlaki was eventually killed by an American drone strike in Yemen in 2011 (Mazetti $\&$ Ors 2013). But the influence he exerted, even after death, remains. For example, Dzhokhar Tsarnaev, who was responsible for the Boston Marathon bombing in 2013, was a self-radicalized jihadist. His audio collection included speeches and videos of al-Awlaki (O'Neill 2015). Indeed, America's worst domestic shooting, the killing of 49 people and the wounding of 53 others at the Pulse nightclub in Orlando in 2016, was committed by Omar Mateen, who had been influenced by watching videos of al-Awlaki (Shane 2016).

\section{[D] THE SIGNIFICANCE OF FREEDOM OF EXPRESSION IN THE UK AND USA}

The HRA incorporates the ECHR into UK law. One of these rights is Article 10(1), freedom of expression. As per the case of Handyside, the ECtHR said that, subject to Article 10(2), the right was applicable not only to information or ideas that were favourably received or regarded as inoffensive or as a matter of indifference, but also to those that offended, shocked or disturbed the state or any sector of the population. Such are the demands of that pluralism, tolerance and broadmindedness without which there was no democratic society. ${ }^{11}$ The First Amendment of the Constitution of the United States protects free speech. Like Article 10(1)

11 See n 1 para 49. 
of the ECHR, it protects speech that is not favourably received. In Matal $v$ Tam, ${ }^{12}$ in SCOTUS, Justice Samuel Alito said:

We have said time and again that the public expression of ideas may not be prohibited merely because the ideas are themselves offensive to some of their hearers ... If there is a bedrock principle underlying the First Amendment, it is that the government may not prohibit the expression of an idea simply because society finds the idea itself offensive or disagreeable. ${ }^{13}$

The ECtHR in Handyside also said that the court's supervisory functions oblige it to pay the utmost attention to the principles characterizing a 'democratic society'. Freedom of expression constituted one of the essential foundations of such a society. A key argument for this is the idea of personal autonomy-the state should not determine what is / is not appropriate for an individual to view, hear, read etc. In FCC $v$ Pacifica Foundation, ${ }^{14}$ SCOTUS famously declared: 'It is a central tenet of [free speech] that the government must remain neutral in the marketplace of ideas.' 15 Indeed, the 'marketplace of ideas' argument is another important consideration in the determination of the significance of freedom of expression. In $R$ (Animal Defenders International) $v$ Secretary of State for Culture, Media and Sport, ${ }^{16}$ for example, the UK's highest court, the House of Lords (as it was then called) said:

The fundamental rationale of the democratic process is that if competing views, opinions and policies are publicly debated and exposed to public scrutiny the good will over time drive out the bad and the true prevail over the false. It must be assumed that, given time, the public will make a sound choice when, in the course of the democratic process, it has the right to choose. ${ }^{17}$

The significance of free speech to countries like the UK and America is not only reliant on domestic law, but also international law: Articles 19 of the Universal Declaration of Human Rights (UDHR) and the International Covenant on Civil and Political Rights (ICCPR) both decry limitations on expression.

\footnotetext{
12137 US 1744 (2017).

13 Ibid 1763.

14438 US 726 (1978).

15 Ibid 745-46.

16 [2008] UKHL 15.

17 Ibid para 28.
} 


\section{[E] THE QUALIFICATION OF FREEDOM OF EXPRESSION IN THE UK AND USA, ESPECIALLY TERROR SPEECH}

Free speech is not unlimited. For example, Article 19(2) of the ICCPR, freedom of expression, is qualified by Article 19(3):

The exercise of the [right] carries with it special duties and responsibilities. It may therefore be subject to certain restrictions, but these shall only be such as are provided by law and are necessary:

(a) For respect of the rights or reputations of others;

(b) For the protection of national security or of public order (ordre public), or of public health or morals.

Indeed, Article 20 of the ICCPR also states: '(1) Any propaganda for war shall be prohibited by law. (2) Any advocacy of national, racial or religious hatred that constitutes incitement to discrimination, hostility or violence shall be prohibited by law.' Regionally, for the purposes of the UK, Article $10(1)$ of the ECHR, freedom of expression, is also qualified in this regard. In Erbakan $v$ Turkey, ${ }^{18}$ the ECtHR said: 'As a matter of principle it may be considered necessary in certain democratic societies to sanction or even prevent all forms of expression which spread, incite, promote or justify hatred based on intolerance.' 19 There is also an express duty to act responsibly within the right, as per Article 10(2) of the ECHR. Furthermore, the test for interpreting breaches of Article 10(1) is 'proportionality', that is whether the limitation on expression is in proportion to the objective of the state, such as protection of national security, prevention of disorder and crime etc. For example, in the above case of Handyside, the applicant, a publisher, was charged and convicted under the Obscene Publications Act 1959 for 'having in his possession obscene books entitled The Little Red Schoolbook for publication for gain'. Copies of the book, which were meant for children over 12 and included information on sex-abortion, homosexuality, intercourse and masturbation etc-were seized, forfeited and later destroyed. The court said that the infringement was in breach of Article 10(1) of the ECHR but was lawful, as per Article 10(2), since the interference was in proportion to the state's aim of protecting health and morals. ${ }^{20}$

\footnotetext{
18 App no 59405/00.

19 Ibid para 56.

20 See n 1 para 49.
}

Series 2, Vol 1, No 2 
Comparatively, there is a much stronger test than proportionality in America, 'strict scrutiny', in reviewing content-based limitations on free speech: see, for example, Adarand Constructors, Inc $v$ Pena. ${ }^{21}$ Indeed, when ratifying the ICCPR, in 1992, the USA filed reservations in respect to Articles 19 and 20 to afford its domestic law on free speech greater protection than the ICCPR seemingly allows. In the past, however, SCOTUS upheld the constitutionality of various statutes that significantly limited freedom of speech under the pressures of world wars, Schenck $v$ United States, ${ }^{22}$ and the perceived communist threat, Dennis $v$ United States. ${ }^{23}$ In Schenck, for example, two defendants were convicted under the Espionage Act of 1917 of inducing conscripted personnel from joining the armed forces. The test then for violations of the First Amendment involved less exacting intensity of review than 'strict scrutiny': 'The question in every case is whether the words used are in such circumstances and are of a such nature as to create a clear and present danger [my italics] that they will bring about the substantive evils that Congress has a right to prevent. ${ }^{24}$

However, after the Second World War, SCOTUS began to take a tougher stance on the protection of free speech, even in cases of perceived speech inciting violence: Yates $v$ United States. ${ }^{25}$ This culminated in the ruling in Brandenburg $v$ Ohio. ${ }^{26}$ In Brandenburg a Ku Klux Klan (KKK) leader was filmed by a local television crew at a rally making racist remarks about returning Black people to Africa and Jews to Israel: 'We're not a revengent organization, but if our President, our Congress, our Supreme Court, continues to suppress the white, Caucasian race, it's possible that there might have to be some revengeance taken. ${ }^{27}$ This was accompanied by KKK sympathizers holding firearms. Brandenburg's original conviction for advocating violence was quashed. The court said: "The constitutional guarantees of free speech ... do not permit a State to forbid or proscribe advocacy of the use of force or of law violation except where such advocacy is directed to inciting or producing imminent lawless action and is likely to incite or produce such action.' ${ }^{28}$ (SCOTUS has since confirmed that

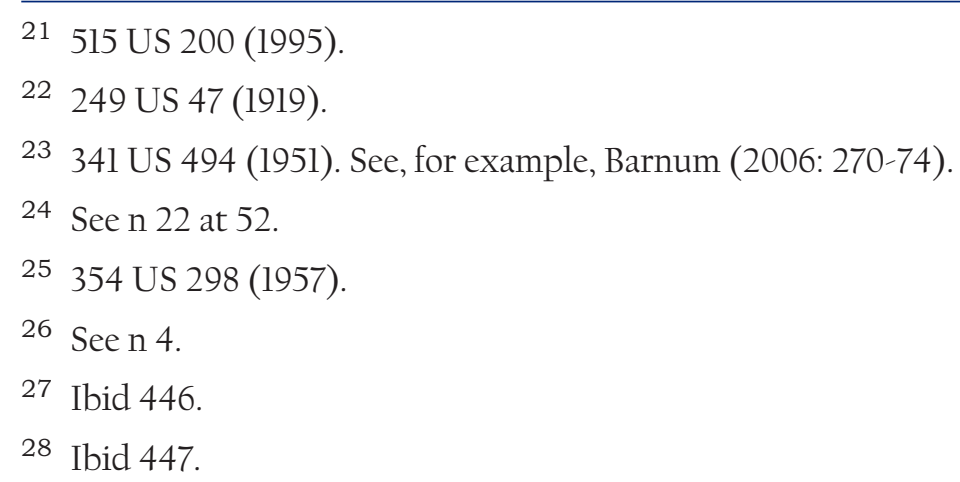


regulation of the internet is afforded the same First Amendment protection as the print media: Reno $v$ ACLU. ${ }^{29}$ )

There are, therefore, three issues to prove for inciting terrorism in America, even if the hate speech is conducted online: 1) imminent harm; 2) the likelihood of that imminent harm; and 3) the intention to directly cite others (Tsesis 2017: 655-67). This is a much narrower test than proportionality for assessing unlawful breaches of Article 10(1) of the ECHR. Thus, there is far more tolerance of hate speech in America than in the UK. ${ }^{30}$ In 2016, the Rock musician Ted Nugent drew fire for insinuating gun control in America was the product of a vast Jewish conspiracy. In a post on Facebook, he showed the faces of several American politicians next to Israeli flags beneath the caption: 'So who is really behind gun control?' In a later post he claimed: 'Jews for gun control are Nazis in disguise.' (Blake 2016) According to Amos Guiora, this is not an instance in which the American government could limit speech online: 'As vile, anti-Semitic, or odious Mr Nugent's posting may be, it need not be removed from social media.' (Guiora 2018: 142) Guiora also references Palestinian terrorist groups' social media posting about running over Jews in cars in 2015. This, too, would be protected by the First Amendment: "This ... is [very] general and [unclear] in its "how to" instructions.' (ibid 143)

\section{[F] ATTEMPTS TO LIMIT TERROR SPEECH IN THE UK AND USA}

With the growing Islamist terror threat after 9/11, the UN Security Council (UNSC), in 2005, passed Resolution 1624 'condemning in the strongest terms the incitement of terrorist acts and repudiating attempts at the justification or glorification (apologie) of terrorist acts that may incite further terrorist acts'. Thus, the resolution, in section 1 , calls upon all states to adopt such measures as may be necessary and appropriate to: (a) prohibit by law incitement to commit a terrorist act or acts; (b) prevent such conduct; and (c) deny safe haven to any persons guilty of such conduct. (More recently, the UNSC has passed Resolution 2178 (2014), in which it addresses the threat of foreign terrorist fighters. The UNSC cites effective implication of Resolution 1624 as an important factor in the effective implementation of Resolution 2178: UNCTED 2016: 5.) Similarly, in the same year as Resolution 1624, in 2005, the CoE

29521 US 844 (1997).

30 SCOTUS is less tolerant of some forms of expression, however, such as child pornography, obscene speech, fraudulent utterances etc—see, for example, Price (2018: 827).

Series 2, Vol 1, No 2 
published the CPT. One of the Articles within the CPT, Article 5(1), obliges states to outlaw 'public provocation to commit a terrorist offence'. This means: 'the distribution, or otherwise making available, of a message to the public, with the intent to incite the commission of a terrorist offence, where such conduct, whether or not directly advocating terrorist offences, causes a danger that one or more such offences may be committed'.

Drawing on its international and regional counter-terror obligations, as well as following the $7 / 7$ bombings in London in 2005, killing 52 people, the UK enacted the Terrorism Act 2006, to disrupt individuals from exploiting the internet for terrorist purposes. Section 1 introduced a new offence of 'encouragement of terrorism'. Section 1(1) applies to a statement that is likely to be understood by some or all of the members of the public to whom it is published as a direct or indirect encouragement or other inducement to them to the commission, preparation or instigation of acts of terrorism. Furthermore, the mental element of the offence, according to section $1(2)$, is that a person publishes a statement and, at the time they publish it, they either (i) intend members of the public to be directly or indirectly encouraged or (ii) are reckless as to whether members of the public will be directly or indirectly encouraged. So, the offence can be committed recklessly, as well as intentionally. For the purposes of indirectly encouraging terrorism, this includes every statement which glorifies the commission or preparation (whether in the past, in the future or generally) of such acts or offences, as per section 1(3). Section 1(5) says that it is irrelevant: (a) whether anything mentioned in those subsections relates to the commission, preparation or instigation of one or more particular acts of terrorism or of acts of terrorism generally; and, (b) whether any person is in fact encouraged or induced by the statement to commit, prepare or instigate any such act or offence. As per section 17, the UK has universal jurisdiction to try encouragements of terrorism committed abroad. The 'public' for whom a statement can either intentionally or recklessly encourage terrorism can be outside the UK, as per section 20(3). Interestingly, in practice, the UK prosecuting authorities have confined the prosecution of the offence to countering international terror groups, meaning there have been no prosecutions against domestic terror groups, particularly in Northern Ireland: 'The absence of any charges being laid for the offence of encouraging terrorism in Northern Ireland appears peculiar. The prevalence of paramilitary murals on walls in Northern Ireland falls well within the scope of the provisions of the Act, which criminalises statements-including images-which encourage or glorify terrorism.' (Blackbourn 2013: 30) 
An example of a person convicted of an offence contrary to section 1 of the Terrorism Act 2006 is Tareena Shakil, who glorified terrorism on social media. Shakil was radicalized on the internet and travelled to Syria via Turkey after telling friends and family she was off on a beach holiday. She spent more than two months living in a mansion and, while there, sent messages and pictures glorifying ISIL, including ones of herself posing with an AK-47 assault rifle (Morris 2019). It was irrelevant that her incitement occurred outside the UK.

If a person distributes, sells, gives, shares etc. the encouragement of terrorism they are committing an offence contrary to section 2 of the Terrorism Act 2006, the 'dissemination of terrorist publications'. A person convicted of an offence contrary to section 2 is Mohammed Gul, who was sentenced to five years' imprisonment for creating jihadi videos between 2008 and 2009 and sharing them online via YouTube. ${ }^{31}$ The prosecuting authorities in the UK may wish to regulate the promotion of terrorist propaganda online in other ways: instead of charging someone with a terror offence, they may wish to prosecute someone contrary to section 1 of the Malicious Communications Act 1988. Here, a person sends either an indecent or grossly offensive electronic communication with the intention of causing distress or anxiety (section 127 of the Communications Act 2003 is a similar offence). This is what happened recently when a man in the UK allegedly supported the recent far-right terror shootings in Christchurch on social media (Grierson and Dodd 2019).

With the strict interpretation of the First Amendment by SCOTUS in Brandenburg, an attempt to limit terror speech, particularly by mirroring the UK's Terrorism Act 2006, would be unconstitutional. Encouragement of terrorism in Britain does not require threats of imminent lawless action, for example (Parker 2007: 748). But America can limit the speech of terrorists in other ways, such as in the case of 'true threats'. A true threat is a statement that is meant to frighten or intimidate one or more specified persons into believing that they will be seriously harmed by the speaker or by someone acting at the speaker's behest (O'Neill 2019). Reference to the degree of harm and the First Amendment is the ruling of SCOTUS in Watts $v$ United States, ${ }^{32}$ which was in the same year as Brandenburg, 1969. At a very public, political forum-an anti-Vietnam War rally-the defendant allegedly said to a large crowd: 'If they ever make me carry a

31 This was the subject of an appeal on a point of law to the UK's highest court, the Supreme Court, on the subject of, for example, the extra-territorial effect of the definition of terrorism in section 1 of the Terrorism Act 2000: Rv Gul [2013] UKSC 64.

32394 US 705 (1969). 
rifle the first man I want to get in my sights is LBJ [a reference to the then President of the United States Lyndon B Johnson].' Watts's conviction for advocating violence against the President was quashed-SCOTUS did not believe his statement had constituted a 'true threat'. 'Political hyperbole' was protected by the First Amendment. ${ }^{33}$ The law on true threats was developed in the later case of Virginia v Black: "34 "True threats" encompass those statements where the speaker means to communicate a serious expression ... to commit an act of unlawful violence to a particular individual or group of individuals'. ${ }^{35}$ A speaker therefore need not actually intend to carry out the threat, but they must actually intend, through a statement, to instil fear in the recipient (O'Neill 2019). There is no need to prove that a recipient was actually in fear of harm (Tsesis 2017 669). And the true threats doctrine, unlike Brandenburg, does not contain an imminence component (ibid 667). Thus, this type of expression is reflective of terrorist speech on the internet (ibid), but, of course, one or more specified persons have to be targeted, so vague ideas about jihad will be excluded.

There are other ways in which terror speech in the US can be limited, which do not engage the Brandenburg test, as the ruling of SCOTUS in Holder $v$ Humanitarian Law Project ${ }^{36}$ illustrates. The court ruled that a criminal prohibition on advocacy carried out in coordination with, or at the direction of, a foreign terrorist organization was not an unconstitutional infringement of freedom of speech. The offence in question was 'providing material support or resources to designated foreign terrorist organizations', contrary to section 2339B of Title 18 of the United States Code, Crimes and Criminal Procedure. The Humanitarian Law Project was therefore prevented from providing support to Partiya Karkeran Kurdistan (PKK), even though this was for non-terrorist purposes of the organization. It wanted to advise the PKK on how to follow and implement humanitarian and international law and petition various international bodies such as the UN. ${ }^{37}$ The Humanitarian Law Project was also constrained from helping the Liberation Tigers of Tamil Eelam (LTTE) to present claims for tsunami-related aid to international bodies and/or negotiating peace agreements between its

\footnotetext{
33 Ibid 707-08.

34538 US 343 (2003).

35 Ibid 359.

36130 SC 2705 (2010).

37 Ibid 2710-1l.
} 
organization and the Sri Lankan government. ${ }^{38}$ Importantly, the court emphasized that support for these designated organizations freed up other resources within the group to be used for terror ends. And support gave the groups legitimacy-legitimacy that makes it easier for ... groups to persist, to recruit members, and to raise funds-all of which facilitate more terrorist attacks'. ${ }^{39}$ On the significance of Holder for remaining true to the principles of the First Amendment, Daphne Barak-Erez and David Scharia note: "The decision presumably follows the US freedom of speech jurisprudence ... that it affirms a prohibition that abstains from addressing the content of the speech and focuses only on the link between the speaker and the terrorist organisation.' (Barak-Erez and Scharia 2011: 19) There are other ways in which terror speech in America may be curtailed, without being an unconstitutional infringement of the First Amendment: the offences of seditious conspiracy and advocating overthrow of government, contrary to sections 2384 and 2385 of Title 18 of the United States Code, Crimes and Criminal Procedure. ${ }^{40}$

It is important to note, however, that international and regional law demands that speech, even of a 'dubious' nature, should not be arbitrarily curtailed. Above, there was reference to UNSC Resolution 1624. This resolution does oblige states to have regard to Articles 19 of the UDHR and ICCPR. (Similarly, Article 12 of the CPT obliges states to respect their freedom of expression duties in the ICCPR and the ECHR.) Furthermore, UNSC Resolution 1624, which condemns in the strongest terms the incitement of terrorist acts', references condemnation only in the preamble, not the later substantive obligations of the resolution. And, even in the later duties, the term 'prohibit' is only used, not 'criminalize' (Barak-Erez and Scharia 2011:21). Indeed, the UN Counter-Terrorism Committee Executive Directorate (UNCTED), in its global survey of the implementation of UNSC Resolution 1624 by member states in 2016, was keen to stress that the powers exercised by states should only be used for legitimate aims, that is for limiting genuine terror speech, and not for illegitimate aims such as the suppression of political dissent or the advocacy of controversial beliefs or views (UNCTED 2016: 8). Otherwise, the consequences could have the opposite effect of leading to greater radicalization (ibid).

\footnotetext{
38 Ibid.

39 Ibid 2725.

40 Renieris (2009: 701-05) identifies other criminal laws in America which could indirectly limit terror speech, such as immigration violations, visa fraud, providing false statements, credit card fraud and money laundering.
} 


\section{[G] CRITICIZING LIMITATIONS TO TERROR SPEECH IN THE UK}

In criticizing limitations to speech in the UK, is the test for assessing infringements of Article 10(1) of the ECHR, 'proportionality', sufficiently demanding to protect expression, in general? In the case of protection of heath and morals, for example, the courts regularly defer to the interests of the state, as in the case of Handyside, and in the UK domestic interpretation of Article 10(1)—see, for example: Belfast City Council v Miss Behavin' Ltd. ${ }^{41}$ Indeed, is freedom of expression, at least in the UK, becoming much less tolerant of individuals who may cause others offence, meaning the bar for employing proportionality is set too low? In a recent conviction, YouTuber, Mark Meechan, who trained his girlfriend's dog to perform Nazi salutes, was fined $£ 800$ after posting videos of the dog online, in breach of section 127 of the Communications Act 2003. The case provoked widespread concern from comedians and free speech campaigners, including the human rights organization Index on Censorship. Index said that freedom of expression included the right to offend: 'Defending everyone's right to free speech must include defending the rights of those who say things we find shocking or offensive ... Otherwise the freedom is meaningless.' (Dearden 2018)

Where the infringement of Article 10(1) is attributed to terror speech, in particular, the courts interpret the proportionality test much more in favour of the state at the expense of the individual: Leroy $v$ France. ${ }^{42}$ (For the purposes of domestic implementation of the ECHR, the UK courts must have regard to the case law of the ECtHR, as per section 2 of the HRA.) In Leroy a cartoon was published in the Basque weekly Ekaitza, two days after the 9/11 attacks in New York and Washington in September 2001. The cartoon was a caricature representing the attack on the twin towers of the World Trade Center, with a caption stating: 'We have all dreamt of it ... Hamas did it.' Leroy was convicted under French law for complicity in condoning terrorism-the ECtHR found this to be a proportionate interference with Article 10(1). The cartoon not only glorified the terror attacks, but the date of publication, so close to 9/11, was significant. And the effect of the cartoon in a politically sensitive region such as the Basque country was relevant, too, as was Leroy's fine in the French courts, $€ 1500$, which was modest. ${ }^{43}$

\footnotetext{
41 [2007] UKHL 19.

42 See n 3.

43 Ibid paras 36-48. For broader analyses of the UK's Terrorism Act 2006 and the case law of the ECHR, see, for example, Murray (2009)
}

Winter 2020 
However, compare the punishment in Leroy with that of Muhammad Hamza Siddiq, in the UK. Siddiq was recently jailed for four-and-a-half years for using social media to encourage others to commit terrorism. He made a post on his Facebook timeline in which he referred to the struggle of jihad as an obligation that 'is not limited to defensive operations'. The post was liked 67 times and led to an investigation by the police. The officer in charge of the investigation said: "The Facebook post made by Hamza Siddiq was published just months after many people, young and old, lost their lives in UK terror attacks in both London and Manchester. The statement was inflammatory and inciting.' (Counter-Terrorism Policing 2019) Agreeing with the conviction of Siddiq is not difficult, especially as it was an apparent direct encouragement of terrorism, unlike an indirect-condonation-of terrorism in Leroy. But was the length of the sentence, four-and-a-half years, not excessive, especially considering that: it occurred months after the UK terror attacks, not days after 9/11 as in Leroy; it was posted on Facebook, which was only liked 67 times, not published in a weekly newspaper in the politically sensitive Basque country; and resulted in a significant jail-term, not a fine? In domestic law, the British courts must have regard to the case law of the ECtHR, as per section 2 of the HRA. But the clear disparity in outcomes between the two cases suggests that the application of proportionality review, for the purposes of assessing breaches of Article 10, at least domestically, is insufficient to protect expression that allegedly incites violence of a terrorist nature.

Next, criticisms of the specific UK offence of encouragement of terrorism, as per section 1 of the Terrorism Act 2006, are considered. In 2008, for example, the UN Human Rights Committee (UNHRC), in considering the UK's observance of its responsibilities under the ICCPR, was particularly concerned about the effect the offence of encouragement of terrorism had on freedom of expression in general. This was because section 1 was defined in 'broad and vague terms' (UNHRC 2008). There is a worry, therefore, that the broad and vague nature of the offence will inhibit even speech unconnected to terrorism. Hunt states: 'There are concerns that broadcasters, internet service providers, as well as organizations and individuals representing particular categories of legitimate political opinion, may engage in all manner of self-censorship.' (Hunt 2007: 457-58; see also Cram 2006; Bansar 2009) Indeed, more worryingly, rather than countering terrorism, do the measures increase the likelihood of extremism and political violence, which is a previous concern expressed by the UNCTED in states' implementation of UNSC Resolution 1624? At the time the Terrorism Bill 2005 was progressing 
through Parliament, Human Rights Watch expressed concern that the very communities whose support was needed in the fight against terrorism would be alienated (Human Rights Watch 2005). ${ }^{44}$

In specific terms, dismay can be expressed about encouraging an act of terrorism, since an act of terrorism in the UK is not in itself an offence. So, it outlaws conduct, albeit in statements, that is not, strictly speaking, an offence known to law (Jones \& Ors 2006: 15). The wide definition of terrorism in the UK, as per section 1 of the Terrorism Act 2000, is also problematic. Broadly, the definition of terrorism in the UK involves either serious violence against people or property or creates a serious risk to public safety, in advancing either a racial, religious, political or ideological objective, for the purposes of either intimidating the public or influencing the government or a foreign government. In 2013, for example, in $R v$ $\mathrm{Gul}^{45}$ the UK's Supreme Court said: 'While acknowledging that the issue is ultimately one for Parliament, we should record our view that the concerns and suggestions about the width of the statutory definition [of terrorism] ... merit serious consideration. ${ }^{.46}$

Within the UK definition of terrorism, Human Rights Watch is particularly concerned with the term 'influence'; for them, it is too low a threshold for targeting the state (Human Rights Watch 2005: 9). According to a previous Independent Reviewer on Anti-Terror Legislation in the UK, David Anderson QC, 'influence' draws the definition so broadly that it can mean political journalists and bloggers are subject to the full range of anti-terrorism powers, if they threaten to publish or prepare to publish something that the authorities think may be dangerous to life, public health or public safety. With 'influence' the UK definition is so broad it could even catch a campaigner who voices religious objections to a vaccination campaign on the grounds that they are a danger to public health (Anderson 2014: 27-32). Similar concerns were also expressed by the UNHRC, in 2015, in that year's report on the UK's compliance with the ICCPR (UNHRC 2015: para 14).

Section 1(5) of the Terrorism Act 2006 says that it is irrelevant (a) whether anything mentioned in those subsections relates to the commission, preparation or instigation of one or more particular acts of terrorism or of acts of terrorism generally. Anderson is concerned that it is unnecessary to show that specific acts of terrorism are being

\footnotetext{
44 On this issue more generally, see, for example, Awan (2012).

45 See $n 31$.

46 Ibid para 62.
} 
encouraged (Anderson 2012: 123). Under the CPT it will be recalled that an incitement should only be unlawful where it 'causes a danger' that a terrorist act might be committed. There must therefore be a causal link between a hateful statement and the act that is to be prevented. Section 1(5) of the Terrorism Act 2006 exceeds this: it says that it is irrelevant whether any person is in fact encouraged or induced by the statement to commit, prepare or instigate any such act or offence. Causality is further attenuated in that 'members of the public' can include anyone in the world (Human Rights Watch 2005: 10). On this latter issue Jones and others further note:

It is not clear how a court ... is to identify 'the member of the public'... The larger the class of person who may read or hear the statement, the more obvious are the problems...The larger, and more diverse, the 'members of the public' may be, the more difficult will be the evidential proving that...members of the public may be susceptible to such statements so as to consider them as an inducements to the commission of acts of terrorism. (Jones \& Ors 2006: 13)

Section 1(1) also says: 'some ... members of the public'. In addition to the evidential problems concerned with the meaning of 'public', how many people actually constitute 'some' (ibid 12)?

Concern has been expressed about the mental element ingrained within section 1 , too. In implementing its CoE obligations, the UK also went further than it was required to do so in the CPT. It will be recalled that Article 5 defines a public provocation to commit a terrorist offence as intentionally inciting the commission of a terrorism offence. Section 1 does expressly reference the intentional encouragement of terrorism, but, unlike the CPT, it permits the offence to be conducted recklessly. In 2005 when the then Terrorism Bill was progressing through Parliament, alarm was expressed that a person could encourage terrorism without realizing it (Human Rights Watch 2005: 10). ${ }^{47}$

As per section 1, terrorism can be indirectly encouraged, of which glorification, whether in the past, present or future, is a feature. This has drawn particular criticism for being too wide and unclear. Certainty in the law is a key criterion of human rights norms. Article 7 of the ECHR is 'no punishment without law'. This clearly references the rule of law but has been widely interpreted as also requiring legal clarity. ${ }^{48}$ Moreover, in curtailing Article 10(1) of the ECHR, states cannot do so without relying on limitations that are 'prescribed by law', as per Article 10(2). For this

\footnotetext{
47 For more detailed analyses of the CPT, and its applicability to the UK's Terrorism Act 2006, see, for example, Hunt (2007).

48 See, for example, SWvUK App no 20166/92.
} 
reason, when the Terrorism Bill 2005 was being debated, the Parliamentary Joint Committee on Human Rights (JCHR) called for the removal of references to glorification, for violating this element of Article 10(2) (JCHR 2005: para 34). Finally, unlike the offence in section 1 of the Terrorism Act 2006, the universal jurisdiction rules of the CPT, as per Article 14, are much more limited.

\section{[H] A (GREATER?) BALANCING FREEDOM OF SPEECH WITH NATIONAL SECURITY IN THE USA}

The offence of encouragement of terrorism in the UK is an unlawful interference with free expression. But, conversely, does America's protection of free speech, in the First Amendment, insufficiently attach weight to the rights and freedoms of others, especially the potential victims of terror incitement? There are ways of limiting terror speech in the USA without engaging the First Amendment, such as providing material support to a designated terror organization, as per the ruling of SCOTUS in Holder. Indeed, free speech can be curtailed more directly, as the true threats doctrine illustrates, though the law on this is still developing and is confined, at least currently, to a specified victim or victims. But, in the age of the worldwide web, the USA could do more to limit this classification of free speech, as Guiora observes: 'The 1969 ruling [in Brandenburg] came well before the digital age. We live in a time where clicks and shares spread hate and false information instantaneously across the Internet.' (Guiora 2018: 145) European human rights law clearly does not apply to America. But the values behind Articles 1, 2, 3 and 17 of the ECHR, for example, warrant serious consideration.

Article 1 of the ECHR obliges states to secure the rights of all citizens. What about the equal security of the rights of terror victims? Specifically, Articles 2 and 3 of the ECHR, the right to life and freedom from torture respectively, impose a substantive duty on the state to prevent violations of the rights by non-state actors (though this is not an absolute obligation): see, for example, Osman $v U K{ }^{49}$ Article 17 of the ECHR, prohibition of abuse of rights, is particularly interesting. The general purpose of Article 17 is to prevent individuals or groups with totalitarian aims from exploiting in their own interests the principles enunciated by

49 App no 23452/94. 
the ECHR. In Norwood $v U K,{ }^{50}$ for example, the applicant was a member of the British National Party, an extreme right-wing political party. Between November 2001 and January 2002, the applicant displayed in the window of his first-floor flat a large poster. The poster depicted New York's Twin Towers in flames after 9/11, accompanied by the words 'Islam out of Britain-Protect the British People'. Following a complaint from a member of the public, the police removed the poster. Despite being contacted by the police and invited to attend an interview, Norwood refused to turn up. He was therefore prosecuted. Norwood challenged his subsequent conviction on the grounds of it being a disproportionate interference with Article 10(1) of the ECHR. The ECtHR dismissed his application. To equate the whole of Islam with the 9/11 attacks was in fact an abuse of Article 10, as per Article 17; it denied the rights of others and ignored the fundamental values of the ECHR such as tolerance, social peace and non-discrimination. ${ }^{51}$ The ECtHR upheld a similar case, Ivanov $v$ Russia, ${ }^{52}$ on the same grounds, Article 17, where the applicant had expressed hatred against Jews rather than Muslims (Holocaust denial does not qualify for Article 10 protection either: Garaudy $v$ France) ${ }^{53}$ If the ideas which Article 17 of the ECHR represent were a factor in determining breaches of the First Amendment of the US Constitution, surely Brandenburg's conviction would be upheld?

Linked to the Article 17 argument, to afford less protection in America to content inciting terror, violence is the 'suicide pact' argument-a homage to the dissenting judgment of Justice Robert Jackson, in SCOTUS, in Terminiello $v$ City of Chicago. ${ }^{54}$ In Terminiello the City of Chicago had sought to criminalize speech that provoked public disorder. Arthur Terminiello was giving a speech to the Christian Veterans of America in which he criticized various racial and religious groups such as Jews and made a number of inflammatory, pro-fascist comments. There was a crowd of approximately 1000 people outside, protesting against the speech, some violently. The Supreme Court held that Terminiello's conviction for disorderly conduct was unconstitutional. But Justice Jackson believed that the majority had attached far too much weight to Terminiello's free speech, failing to appreciate the very real concerns of public safety, with two opposing groups, pockets of which

\footnotetext{
50 App no 23131/03.

51 Ibid 4

52 App no 35222/04.

53 App no 65831/01.

54337 US l (1949).
} 
were intent on committing violence against the other. Johnson's dissent in this case is most famous for its final paragraph:

This Court has gone far toward accepting the doctrine that ... all local attempts to maintain order are impairments of the liberty of the citizen. The choice is not between order and liberty. It is between liberty with order and anarchy without either. There is danger that, if the Court does not temper its doctrinaire logic with a little practical wisdom, it will convert the constitutional Bill of Rights into a suicide pact. ${ }^{55}$

The phrase 'suicide pact' is often associated with the former US President, Abraham Lincoln. Lincoln suspended the constitutional right of habeus corpus during the American Civil War, in 1861. According to section 9, clause 2, of Article I, of the US Constitution, The privilege of the writ of habeas corpus shall not be suspended, unless when in cases of rebellion or invasion the public safety may require it.' Was the American Civil War a 'rebellion'? More importantly, however, Article I of the US Constitution references the powers of the legislature-Congress-not the executive-the President. But Congress was not in session (Posner 2006: 39). Lincoln claimed the violation of a constitutional right to save the Constitution so, to him, he was not acting against the Constitution: he was preserving it (ibid 40). Conceptually, one may found the actions of Lincoln during the Civil War, and the 'suicide pact' argument of Justice Robert Jackson in Terminiello, on the state theory of the German constitutional theorist, Carl Schmitt, in his book Dictatorship, first published in 1921 (2014). ${ }^{56}$ Here Schmitt supported the conferring of wide powers on the then German President to protect the state, at the time, from extreme groups seeking to destroy it. Schmitt based the President's

55 Ibid 36.

56 Carl Schmitt famously joined the Nazi Party in 1933 and was its so-called 'Crown Jurist'. So the author is keen to acknowledge that Schmitt is a controversial academic figure and continues to divide opinion. In an email to me dated 12 February 2019, my good friend and noted Schmittian scholar, Michael Salter, wished me to emphasize the following about Schmitt's apparent voluntary joining of the Nazi Party, in 1933: 'Schmitt's pre-1933 writings were not at all Nazi and he was widely regarded as a political enemy of Nazism by the Nazis themselves as well as his socialist Jewish PhD students (such as Franz Neumann and Otto Kirchheimer) because he was aligned with the Nazis' conservative enemies, and they never included his works on their list of approved propaganda ... In 1933 ... he knew he and his family were highly vulnerable to being put in a concentration camp by Hitler's new government so he made dramatic and entirely inconsistent lip service to their cause and received some official positions as a reward, in what was really pretty morally disgusting opportunism. It is always easy for us to think we would have acted entirely differently, given up our legal/academic careers and go into exile rather than collaborate. Most liberal legal academics, lawyers and judges did not however. However, the hard-core Nazis of Himmler's SS never believed Schmitt was sincere (they were right!) and never forgave his earlier attacks and succeeded in having him expelled. It was only the fact that Goering had appointed Schmitt, and was not willing to allow Himmler to depose and kill one of his own appointees, that saved him. Schmitt's religious prejudices, including mild anti-judaism, were of a typical Catholic kind of the time.' For a much less favourable interpretation of Schmitt's anti-Judaism and association with Nazism, see Strong (1996: xviii-xix). 
powers on emergency provisions within Article 48 of the German Constitution of 1919. ${ }^{57}$ This form of constitutional protection was premised on a 'commissarial dictatorship', in that a commissioner dictator was appointed by the sovereign, whose aim was to 'eliminate the danger and to strengthen the foundation which had been threatened' (Schwab 1989: 32-33). ${ }^{58}$

In his later work, Political Theology, dating from 1922, Schmitt determined that the sovereign's commissarial dictator could only be appointed, and the wide powers conferred on them to address the crisis, when it was a state of exception. A state of exception was characterized by a situation of extreme peril and a danger to the existence of the state (Schmitt 2005: 6). In his later works, e.g. Legality and Legitimacy, first published in 1932, Schmitt continued to believe that liberalism was illequipped to protect the state from extremist groups seeking to destroy it. For Schmitt, liberalism's neutrality and tolerance exacerbated the potential for chaos. Extremist groups then abused this neutrality and tolerance for their own political gain (Lazar 2009: 38-40). Of course, the author here is not likening the existing terror threat, post $9 / 11$, to the Schmittian exception, but merely to illustrate that too much respect for hate speech is counter-productive, since extremists do not reciprocate liberal, constitutional ideals of tolerance, social peace and nondiscrimination.

In the age of terrorism post $9 / 11$, therefore, together with the speed, ease and little cost incurred in sharing terror speech on the internet, should there not be a reappraisal of, for example, the Brandenburg ruling? The author is based in the UK. But the UK's approach to limiting terror speech is arguably too intrusive of freedom of expression. Therefore, a compromise approach, a 'third way', between the two jurisdictions is suggested in the following section, though a common definition for both countries is not proposed.

\footnotetext{
57 See Schmitt (2014 180-226), 'Appendix: The Dictatorship of the President of the Reich According to Article 48 of the Weimar Constitution'. To be exact this Appendix was an addition to the second edition of Dictatorship, which was not published until 1928.

58 Indeed, Schmitt's 'commissarial' dictatorship was not a new concept, however: Ancient Rome had many examples of a suspension of the existing order for its self-preservation. Moreover, in The Social Contract, for example, Jean-Jacques Rousseau (1712-1778) dedicated a whole chapter to 'the Dictatorship' to maintain the survival of the state- see Rousseau (1998, book IV: chapter VI, 124 26).
} 


\section{[I] A ‘THIRD WAY’ FOR LIMITING TERROR SPEECH IN THE UK AND USA}

A possible solution to narrowing the reach of terror speech in the UK, for example, would be, first, to revisit the wide definition of terrorism, within section 1 of the Terrorism Act 2000. The term 'influence the government' is particularly contentious, as stated above. But, in the later case of $R$ (Miranda) $v$ Secretary of State for the Home Department, ${ }^{59}$ in the Court of Appeal of England and Wales, Lord Dyson said:

Terrorism as it is ordinarily understood is the attempt to advance some political or religious cause not by persuasion but by violence, the endangerment of life etc. To describe a newspaper writing political stories that inadvertently reveal the identity of members of the intelligence service or oppose government policy on vaccination as committing an act of terrorism is to use the word terrorism in a way that bears no relationship to any ordinary understanding of the concept. ${ }^{60}$

So, for the purposes of influencing the government, since Miranda there has to be some mental element such as intention, or at least recklessness, to commit an act of terrorism. The Court of Appeal clearly narrowed the reach of the definition by requiring some form of mens rea on the part of a criminal suspect, through statutory interpretation, but it had no power to literally change the legislature's conscious use of the word 'influence'. For comparison, at the international level, the UN's Draft Comprehensive Convention Against International Terrorism 2002 defines terrorism, in Article 2(1), as including 'to compel [my italics] a Government or an international organization'. 'Compel' is of course a higher standard than 'influence'. This UN Convention is yet to be agreed, but the same words, 'compel a Government', have been adopted by the UNSC, for example, in its Resolution 1566 of 2004. Indeed, the EU even adopts a higher standard than compel: 'unduly compel', in Article 3(2)(b) of its Directive 2017 / 541 on combatting terrorism. Paying particular attention, therefore, to the breadth of the UK's definition of terrorism is certainly one way of limiting the effect the offence of encouragement of terrorism has on freedom of expression.

The ruling of the Court of Appeal in Miranda imposed a mental element within the definition of terrorism in the UK, but concern about the mental element for the substantive offence of encouragement of terrorism still remains. It will be recalled that the CPT suggests only a standard of

59 [2016] EWCA Civ 6.

60 Ibid para 48. 
intention, so the reference to recklessness in section 1 should be removed; indeed, advocating violence in America, as per Brandenburg, requires intention. Miranda is not the only 'reform' to the reach of the offence of encouragement of terrorism since its inception in 2006: recently, the UK enacted a new piece of relevant legislation, the Counter-Terrorism and Border Security Act 2019. Section 5 amends section 1 of the Terrorism Act 2006: 'Some ... members of the public' is replaced by 'a reasonable person'.

The concerns previously expressed about the reach of the term 'public', and the exact number of people required to constitute 'some', have apparently been addressed by section 5 of the Counter-Terrorism and Border Security Act 2019. This is to be welcomed. But, in addition to the issue of recklessness, the exclusion of proof that a crime could actually be committed remains. Under the CPT it will also be recalled that an incitement should only be unlawful where it 'causes a danger' that a terrorist act might be committed. There should therefore be some causal link between a hateful statement and the act that is to be prevented. This is another issue, after the requirement of intention, where the UK and US offences could conceivably overlap. In America the requirement that the speech likely incites or produces imminent lawless action, as per Brandenburg, should be relaxed: the CPT only references a danger that such an offence may be committed. (True threats do not carry an element of imminence but, of course, have their own limitations, such as a specified victim or victims.) If so, this could represent something of a return to a 'clear and present danger' type of test adopted by SCOTUS in, for example, Schenck in $1919 .{ }^{61}$ A final way of negotiating the limits to free speech in the UK and America could be to tighten the proportionality test by employing some elements of strict scrutiny and/or loosening the strict scrutiny test by employing some elements of proportionality.

\section{[J] CONCLUSION}

Following the recent terror shooting in Christchurch, the British Home Secretary, Sajid Javid, said that online platforms had a responsibility not to do the terrorists' work for them: 'This terrorist filmed his shooting with the intention of spreading his ideology ... Allowing terrorists to glorify in the bloodshed or spread more extremist views can only lead to more radicalisation and murders.' (Gayle 2019) This is a legitimate argument.

61 Interestingly, there has been a growing support in the case law of the ECtHR for a test to be applied in cases of terror speech that is similar to the US Supreme Court's 'clear and present danger' standard - see, for example, Dyer (2015). Dyer argues that the ECtHR should adopt a test under which there is but one enquiry: 'did the impugned speech create a real risk of violence?' 
The spectacular rise of Islamist terrorism after 9/11, with the enduring threat Islamism poses, justifies curtailments of terror speech, especially online. Indeed, the recent terror attack in Christchurch cannot be blamed on Islamism: the terrorist was a neo-Nazi. In the UK and elsewhere the rise of far-right political violence is of particular concern (Osborne 2018). But existing provisions in the UK to prevent terror speech, and the sharing of it, online are surely sufficient? If anything, they go too far. The offence of encouragement of terrorism, as per section 1 of the Terrorism Act 2006, is a disproportionate interference with freedom of expression. This is despite recent limitations on the scope of the crime by the Court of Appeal of England and Wales in Miranda and the enactment of section 5 of the Counter-Terrorism and Border Security Act 2019. The definition of terrorism in the UK, including the term 'influence', as per section 1 of the Terrorism Act 2000, is too wide; the offence can be committed recklessly, as well as intentionally; and there is no need to show a real risk that someone may be encouraged by the speech. These issues need addressing.

Comparatively, limitations on terror speech in America can only be committed intentionally, as per the rulings of SCOTUS in Brandenburg (though for true threats there is only an intention to state something that puts a person in fear, not to intend that a person is actually put in fear). But the respect for free speech in this instance, because of the demands of the First Amendment, date from, in the case of Brandenburg, 1969. This is obviously unreflective of the internet age, in the 21 st century. European human rights law, arising from Articles 2 and 3 of the ECHR, imposes positive obligations on states to prevent violations of death and serious harm from third parties such as terrorists (though these are not unqualified duties). The recent terror attacks at churches in Sri Lanka, in April 2019, in retaliation for the Christchurch shootings, could have been avoided if the Sri Lankan authorities had acted on intelligence passed on to them from foreign governments (Burke and Safi 2019). This is a human rights violation by Sri Lanka, although it was not the perpetrator of the attack. SCOTUS has upheld indirect restrictions on terror speech in Holder, but a reflection of these other values, from within European human rights law, could entail a reconsideration of the American requirement of imminent lawful action; a danger that harm might be committed should be sufficient, mirroring, to some degree, the old test of 'clear and present danger' in Schenck.

Some academics in America are strongly resistant to reappraising the doctrine from Brandenburg, even in the context of limiting terror speech. For them this will 'easily send us skidding down a quite slippery slope' 
(Price 2018: 845). There is also a legitimate question whether genuine attempts by states to honour their international and regional responsibilities to limit the advocation of terrorist violence are, in practice, effective. Terrorists intent on sharing information can do so privately through encrypted messaging services such as WhatsApp and Telegram (Waterson 2019). And the perpetrator of the recent postal attacks in the USA, in October 2018, used the dark web for information-16 packages containing pipe bombs were sent to several prominent critics of US President Donald Trump (Swaine and Holpuch 2018). So, whilst the restrictions proposed here may not stop hard-line ideologists, or even those on the cusp of extremism and violence, effective counter-terror strategy involves 'preventing' individuals from being radicalized. Contentbased restrictions challenge traditional liberal constitutional ideals of tolerance, but tolerance only goes so far before, as the German constitutionalist theorist Carl Schmitt predicted, it becomes self-defeating and injurious to society.

\section{References}

Anderson, David (2012) The Terrorism Act in 2011: Report of the Independent Reviewer on the Operation of the Terrorism Act 2000 and Part 1 of the Terrorism Act 2006.

Anderson, David (2014) The Terrorism Act in 2013: Report of the Independent Reviewer on the Operation of the Terrorism Act 2000 and Part 1 of the Terrorism Act 2006.

Awan, Imran (2012) 'Glorifying and Encouraging Terrorism: Preserving the Golden Thread of Civil Liberties in Britain' 4(3) Journal of Aggression, Conflict and Peace Research 144-54.

Bansar, Davis (2009) 'Speaking of Terror: A Survey of the Effects of Counter-terrorism Legislation on Freedom of the Media in Europe' 7 International Journal of Civil Society Law 33-50.

Barak-Erez, Daphne and David Scharia (2011) 'Freedom of Speech, Support for Terrorism, and the Challenge of Global Constitutional Law' 2 Harvard National Security Journal 1-30.

Barnum, David (2006) 'Indirect Incitement and Freedom of Speech in Anglo-American Law' European Human Rights Law Review 258-80.

$B B C$ News (2010) 'Woman Jailed for Life for Attack on MP Stephen Timms' 3 November 2010

$B B C$ News (2016a) 'Record Number of EU Terror Attacks Recorded in 2015'20 July 2016. 
BBC News (2016b) 'Terrorism Most Immediate Threat to UK, says MI6' 8 December 2016.

Blackbourn, Jessie (2013) 'The UK's Anti-terrorism Laws: Does their Practical Use Correspond to Legislative Intention?' 8 Journal of Policing, Intelligence and Counter-Terrorism 19-34.

Blake, Andrew (2016) 'Ted Nugent Blames Jews for Gun Control in Facebook Posts' The Washington Times 9 February 2016.

Burke, Jason and Michael Safi (2019) 'Sri Lanka Told of Extremist Network Months before Blasts-Sources' The Guardian 24 April 2019.

Chadwick, Elizabeth (2007) 'The 2005 Terrorism Convention: A Flexible Step too far?' 16 Nottingham Law Journal 29-43.

Counter-Terrorism Policing (2019) 'Man Jailed for Encouraging Terrorism' 22 February 2019.

Cram, Ian (2006) 'Regulating the Media: Some Neglected Freedom of Expression Issues in the United Kingdom's Counter-terrorism Strategy' 18 Terrorism and Political Violence 335-55.

Dearden, Lizzie (2018) 'Man who Taught Girlfriend's Pet Pug Dog to Perform Nazi Salutes Fined \&800’ The Independent 23 April 2018.

Dodd, Vikram and Jamie Grierson (2016) 'Revealed: How Anjem Choudary Influenced at Least 100 British Jihadis' The Guardian 16 August 2016.

Dodd, Vikram and Josh Halliday (2018) 'Police Thwart Possible Isisinspired Plot after Newcastle Arrest' The Guardian 11 December 2018.

Dyer, Andrew (2015) 'Freedom of Expression and the Advocacy of Violence: Which Test should the European Court of Human Rights Adopt?' Netherlands Quarterly of Human Rights 78-107.

Gardham, Duncan and Con Coughlin (2010) 'Anwar al-Awlaki: MI5 Warns of the al-Qaeda Preacher Targeting Britain' The Telegraph 11 June 2010.

Gayle, Damien (2019) 'Christchurch Attack: Tech Firms must Clean up Platforms-Javid' The Guardian 16 March 2019.

Grierson, Jamie and Vikram Dodd (2019) 'Police Declare Stabbing in Surrey a Terrorism Incident' The Guardian 17 March 2019.

Grierson, Jamie, Vikram Dodd and Jason Rodrigues (2016) 'Anjem Choudary Convicted of Supporting Islamic State' The Guardian 16 August 2016.

Guiora, Amos (2018) 'Inciting Terrorism on the Internet: The Limits of Tolerating Intolerance' in Anne Bayefsky and Laurie Blank (eds) Incitement to Terrorism Leiden: Brill, 137-49. 
Halliday, Josh, 'Police Warn Sharing James Foley Killing Video is a Crime' The Guardian 20 August 2014.

Hunt, Adrian (2006) 'The Council of Europe Convention on the Prevention of Terrorism' 12 European Public Law 603-28.

Hunt, Adrian (2007) 'Criminal Prohibitions on Direct and Indirect Encouragement of Terrorism' [2007] Criminal Law Review 441-58.

Human Rights Watch (2005) Briefing on the Terrorism Bill 2005 November 2005.

Institute for Economics and Peace (2018) The Global Terrorism Index 2018 November 2018.

Institute for Economics and Peace (2019) The Global Terrorism Index 2019 November 2019.

Johnston, Chris (2017) 'Two Detained under Terrorism Act as UK Arrests Reach Record High' The Guardian 29 November 2017.

Joint Committee on Human Rights (2005) Third Report Session 2005-06: Counter-Terrorism Policy and Human Rights 28 November 2005.

Jones, Alun; Rupert Bowers and Hugo Lodge (2006) Blackstone's Guide to the Terrorism Act 2006 Oxford: Oxford University Press.

Kenbar, Billy (2013) 'Nidal Hasan Convicted of Fort Hood Killings' The Washington Post 23 August 2013.

Lazar, Naomi Claire (2009) States of Emergency in Liberal Democracies Cambridge: Cambridge University Press.

Mair, David (2017) '\#Westgate: A Case Study: How al-Shabaab Used Twitter during an Ongoing Attack' 40 Studies in Conflict and Terrorism 24-43.

Mazzetti, Mark, Charlie Savage and Scott Shane (2013) 'How a US Citizen Came to be in America's Cross Hairs' New York Times 9 March 2013.

Morris, Steven (2016) 'British Woman who Joined Isis in Syria Guilty of Encouraging Terror Acts' The Guardian 29 January 2016.

Murray, Darragh (2009) 'Freedom of Expression, Counter-terrorism and the Internet in Light of the UK Terrorist Act 2006 and the Jurisprudence of the European Court of Human Rights' Netherlands Quarterly of Human Rights 331-60.

Osborne, Samuel (2018) 'Number of Far-right Terror Attacks Increases as Overall Deaths from Terrorism Fall, Report Finds' The Independent 5 December 2018. 
O'Neill, Ann (2015) 'The 13th Juror: The Radicalization of Dzhokhar Tsarnaev' Cable News Network 30 March 2015.

O’Neill, Kevin Francis (2019) 'True Threats' in The First Amendment Encyclopedia.

Parker, Ellen (2007) 'Implementation of the UK Terrorism Act-The Relationship between Counter-terrorism Law, Free Speech, and the Muslim Community in the United Kingdom versus the United States' 21 Emory International Law Review 711-57.

Posner, Richard (2006) Not a Suicide Pact: The Constitution in a Time of National Emergency Oxford: Oxford University Press.

Press Association (2016) 'Twitter and YouTube would not Remove Anjem Choudary's Posts, Court Told' The Guardian 16 August 2016.

Price, Zachary (2018) 'Our Imperiled Absolutist First Amendment' 20 Journal of Constitutional Law 821-48.

Renieris, Elizabeth (2009) 'Combating Incitement to Terrorism on the Internet: Comparative Approaches in the United States and United Kingdom and the Need for an International Solution' 11 Vanderbilt Journal of Entertainment and Technology Law 673-709.

Rudner, Martin (2017) “Electronic Jihad": The Internet as Al Qaeda's Catalyst for Global Terror' 40 Studies in Conflict and Terrorism 10-23.

Rousseau, Jean-Jacques (1998) The Social Contract Ware: Wordsworth Editions.

Schmitt, Carl (2005) Political Theology Chicago: University of Chicago Press.

Schmitt, Carl (2014) Dictatorship Cambridge: Polity Press.

Schwab, George (1989) The Challenge of the Exception: An Introduction to the Political Ideas of Carl Schmitt between 1921 and 1936 2nd edn Westport, Connecticut: Greenwood Press.

Shane, Scott (2016) 'The Enduring Influence of Anwar al-Awlaki in the Age of the Islamic State' 9 Counter Terrorism Center Sentinel 15-19.

Shane, Scott (2017) 'Inside Al Qaeda's Plot to Blow up an American Airliner' The New York Times 22 February 2017.

Stewart, Heather and Jessica Elgot (2018) 'May Calls on Social Media Giants to Do More to Tackle Terrorism’ The Guardian 24 January 2018.

Strong, Tracey (1996) 'Foreword' in Carl Schmitt The Leviathan in the State Theory of Thomas Hobbes: Meaning and Failure in a Political Symbol Chicago: University of Chicago Press, vii-xxviii. 
Swaine, Jon and Amanda Holpuch (2018) 'Pipe Bomb Investigation: Florida Mail Facility Searched by FBI and Police' The Guardian 26 October 2018.

Tsesis, Alexander (2017) 'Terrorist Speech on Social Media' 70(2) Vanderbilt Law Review 651-708.

United Nations Counter-Terrorism Committee Executive Directorate (2016) Global Survey of the Implementation of Security Council Resolution 1624 (2005) by Member States 21 January 2016.

United Nations Human Rights Committee (2008) Concluding Observations of the Human Rights Committee: United Kingdom of Great Britain and Northern Ireland CCPR/C/GBR/CO/6 30 July 2008.

United Nations Human Rights Committee (2015) Concluding Observations on the Seventh Periodic Report of the United Kingdom of Great Britain and Northern Ireland CCPR/C/GBR/CO/7 17 August 2015.

Waterson, Jim (2019) 'Facebook Removed 1.5m Videos of New Zealand Terror Attack in First 24 hours' The Guardian 17 March 2019.

\section{Legislation Cited}

Communications Act 2003 (UK)

Constitution of the United States 1787

Council of Europe Convention on the Prevention of Terrorism 2005

Counter-Terrorism and Border Security Act 2019 (UK)

Directive (EU) 2017/541 of the European Parliament and of the Council of 15 March 2017 on Combating Terrorism and Replacing Council Framework Decision 2002/475/JHA and Amending Council Decision 2005/671/JHA

Espionage Act of 1917 (USA)

European Convention on Human Rights 1950

Human Rights Act 1998 (UK)

International Covenant on Civil and Political Rights 1966

Malicious Communications Act 1988 (UK)

Obscene Publications Act 1959 (UK)

Terrorism Act 2000 (UK)

Terrorism Act 2006 (UK)

Title 18 of the Unites States Code, Crimes and Criminal Procedure 
United Nations Draft Comprehensive Convention Against International Terrorism 2002

United Nations Security Council Resolution 1566 (2004)

United Nations Security Council Resolution 1624 (2005)

United Nations Security Council Resolution 2178 (2014)

Universal Declaration of Human Rights 1948

\section{Cases Cited}

Adarand Constructors, Inc v Pena 515 US 200 (1995)

Belfast City Council v Miss Behavin' Ltd [2007] UKHL 19

Brandenburg v Ohio 395 US 444 (1969)

Dennis $v$ United States 341 US 494 (1951)

Erbakan v Turkey App no 59405/00

FCC $v$ Pacifica Foundation 438 US 726 (1978)

Garaudy v France App no 65831/01

Handyside $v$ UK App no 5493/72

Holder v Humanitarian Law Project 130 SC 2705 (2010)

Ivanov v Russia App no 35222/04

Leroy $v$ France App no 36109/03

Matal $v$ Tam 137 US 1744 (2017)

Norwood $v$ UK App no 23131/03

Osman v UK App no 23452/94

$R$ (Animal Defenders International) $v$ Secretary of State for Culture, Media and Sport [2008] UKHL 15

$R v$ Gul [2013] UKSC 64

$R$ (Miranda) $v$ Secretary of State for the Home Department [2016] EWCA Civ 6

Reno $v$ ACLU 521 US 844 (1997)

Schenck $v$ United States 249 US 47 (1919)

SW v UK App no 20166/92

Terminiello $v$ City of Chicago 337 US 1 (1949) 
Virginia v Black 538 US 343 (2003)

Watts $v$ United States 394 US 705 (1969)

Yates $v$ United States 354 US 298 (1957) 